\title{
Проблемы создания
}

\section{государственных резервов в целях обеспечения продовольственной безопасности в переговорах ВТО}

Создание продовольственных запасов стало одной из важнейших тем переговоров в рамках ВТО при обсуждении правил регулирования торговли сельскохозяйственными товарами. В известной мере это явилось отражением общей тенденции роста значения тематики, связанной с решением глобальных проблем в многосторонних переговорах по торговым и экономическим вопросам. Некоторые исследователи даже говорят о тенденции все большего влияния «гуманизации» на регулирование. В частности, она проявляется в признании возможности мотивировать регулятивные решения стремлением обеспечения продовольственной безопасности либо решения социальных проблем. На глобальном уровне такая идеология используется довольно активно: многие международные организации (ФАО, ЮНКТАД, ВТО) стремятся выработать политику регулирования, способствующую решению глобальных проблем и при этом не противоречащую правилам многостороннего регулирования торговли.

Положения по созданию запасов в целях продовольственной безопасности содержатся в приложении 2 к Соглашению по сельскому хозяйству ВТО (п. 3 и 4 , сноски 5 и 6 ).

Предложения по выработке положений по созданию запасов в целях продовольственной безопасности в рамках ВТО в хронологическом порядке приведены в таблице.

В ходе 9-й Министерской конференции в декабре (Бали, 2013 г.) членам ВТО удалось договориться о начале консультаций по снятию ограничений для развивающихся стран при закупках для государственных резервов в целях обеспечения продовольственной безопасности, результаты которых будут рассмотрены в ходе 11-й Министерской конференции в 2017 г. До этого времени для случаев нарушения уровня поддержки при субсидировании таких закупок установлен «мораторий» на обжалование в суде ВТО.

1 Цуканова Татьяна Владимировна - советник Постоянного представителя Российской Федерации при ВТО. 


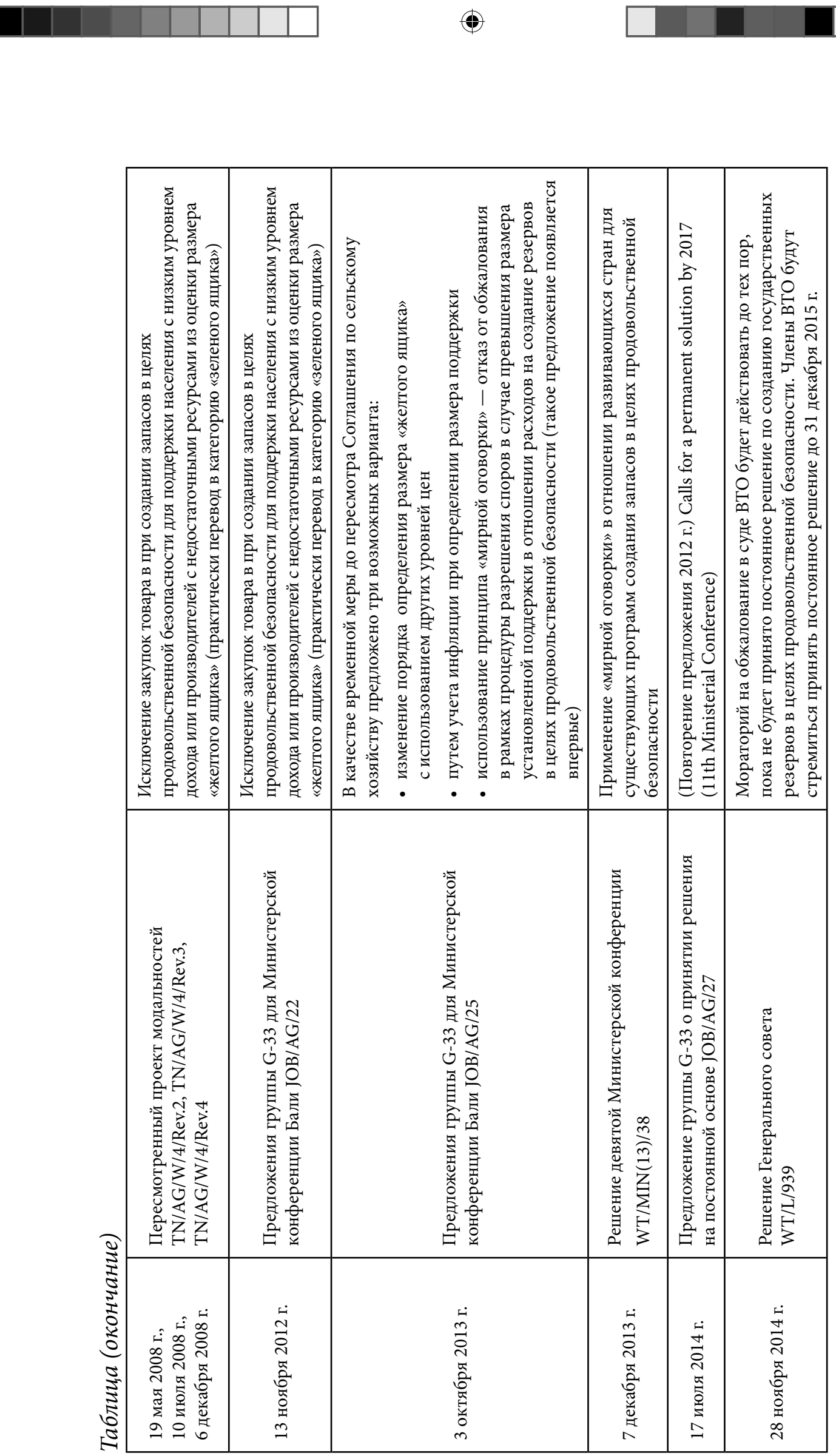
Однако в ходе конференции на Бали развивающиеся страны во главе с Индией добились только того, что защита от судебных исков действует до 2017 г. и для закупок по программам, принятым на 11 декабря 2013 г. Но даже такая уступка для развивающихся стран - членов ВТО не была «подарком». Решение удалось провести только потому, что Индия увязала его с договоренностью по упрощению торговых процедур - соглашением, направленным на либерализацию торговой политики в области таможенного администрирования. Более же амбициозное предложение развивающихся экономик о возможности осуществлять государственные закупки по гарантированным ценам у бедных и/или ограниченных в ресурсах производителей с целью поддержания беднейших фермеров и решения проблемы голода без ограничений (в качестве элемента специального и дифференцированного режима) западными странами была категорически отвергнута.

Именно Индии принадлежала ключевая роль в отстаивании интересов сельского хозяйства - отрасли, являющейся гарантом продовольственной безопасности. Свою позицию Индия объясняла тем, что с 2012 г. безрезультатно добивается снятия ограничений для формирования государственных резервов с целью обеспечения продовольственной безопасности.

В ВТО такая мера трактуется как субсидия, искажающая торговлю. Поэтому развивающиеся страны не могут превышать при проведении таких программ согласованный уровень поддержки ${ }^{1}$. В показателе объема субсидий учитывается разница между специальной ценой закупки продукта (определяется на уровне или выше текущих мировых цен) и его внешней справочной ценой, зафиксированной на уровне мировых цен 1986 г. Пришедшее к власти в мае 2014 г. правительство Н. Моди опасалось, что в условиях, когда мировые цены на продовольствие значительно выросли, разница не позволит Индии «уместиться» в рамках разрешенной поддержки, особенно с учетом существенного объема закупок (запасы государственных резервов по пшенице оцениваются в 39, 8 млн т, по рису - 21,2 млн т) ${ }^{2}$.

В 2013 г. В указанных целях правительство Индии потратило на закупки чуть менее 15 млрд долл., а с 2014 г. запланировано ежегодно осуществлять закупки на сумму около 12 млрд долл. Индия апеллирует к «несправедливости» расчета относительно цен 1986 г. и упирает на социальную значимость таких программ: они принимаются для поддержки беднейших фермеров и способствуют решению проблемы голода. По словам министра торговли и промышленности Индии Н. Ситарамана, развивающиеся страны, такие как Индия, должны иметь право использовать продовольственные резервы для борьбы с голодом без оглядки на международные обязательства, как

1 Не более 10\% общей стоимости всей произведенной в течение года в стране сельскохозяйственной продукции. 
свое суверенное право. Обеспечение гражданам фундаментальных прав на жизнь и пропитание - обязанность правительств.

Однако в 2014 г. В рамках ВТО развернулась дискуссия экономического характера о рисках закупки правительством продовольствия у фермеров по специальным ценам (зачастую выше мировых), что стимулирует фермеров производить больше, чем необходимо, и негативно влияет на международную торговлю.

В качестве примера искажающего торговлю эффекта приводилась ситуация с созданием субсидируемых запасов риса-сырца в Таиланде в 2012 г., приведшая к взрывному росту цен, существенному ущербу национальному производству риса и потере позиций на региональных и мировых рынках. Покупка государством риса по завышенной по сравнению с рынком цене сделала тайский рис дороже на 100-150 долл. за тонну, чем у основных стран-конкурентов, что вызвало снижение экспорта в 2012 г. до 6,73 млн т стоимостью 4,63 млрд долл. по сравнению с 10,7 млн т на сумму 6,43 млрд долл. годом ранее. Правительство избавлялось от запасов, достигших из-за падения экспорта в 2014 г. 17 млн т, и продавало накопленный рис по демпинговым ценам, что привело к искажению цен на мировом рынке.

В контексте тайского примера отмечалось, что Индия, являясь крупным мировым экспортером риса (экспорт неуклонно рос с 2009 г. и составил в 2013 г. 11,4 млн т на сумму 8,2 млрд долл.), начала с 2011 г. экспортировать и пшеницу (поставки в 2013 г. составили 4,3 млн т на сумму 1,3 млрд долл.) ${ }^{1}$. Эксперты высказывали предположение, что при определенных условиях индийские зерновые из государственных резервов могут быть поставлены на внешний рынок. Отмечался потенциальный риск того, что увеличение объемов продовольственных запасов в Индии и экспорт излишков пшеницы из них может привести к снижению цен на зерновые на мировом рынке и затронуть интересы крупных экспортеров зерна, в числе которых называлась и Россия.

В качестве альтернативы эксперты предлагали Нью-Дели рассмотреть другие эффективные меры обеспечения продовольственной безопасности, разрешенные правилами ВТО, негативный эффект которых нивелируется отсутствием связи с физическими объемами производимой продукции. К таким мерам относятся прямые выплаты производителям и внутренняя продовольственная помощь.

В отсутствие прогресса на переговорах по продовольственной безопасности в июле 2014 г. Нью-Дели заблокировал проект решения Генерального совета ВТО о включении Соглашения по упрощению торговых процедур в нормативную базу ВТО и потребовал пересмотра балийского решения, в частности, автоматического продления «мирной» оговорки до тех пор, пока не будет найдено постоянное решение. Индию поддержали Венесуэла, Куба и Боливия.

По данным статистики UNCOMTRADE. 
Индия находилась под огнем критики за то, что «право вето» она использовала в условиях урегулированной до 2017 г. проблемы и для пересогласования решения. Генеральный директор ВТО Р. Азеведо 31 июля 2014 г. по результатам заседания Генерального совета обратился к главам делегаций, подчеркнув серьезность положения, в котором оказалась организация, и важность дальнейших совместных усилий по разблокированию ситуации.

Тем не менее Индии удалось добиться своего. К ноябрю 2014 г. В ходе активных и сложных консультаций члены ВТО выработали новые формулировки решения по формированию государственных резервов в целях обеспечения продовольственной безопасности. В частности, они предусматривают, что мораторий на обжалование будет действовать до тех пор, пока в ВТО не будет согласовано и принято постоянное решение. Новая договоренность одобрена Генеральным советом организации 28 ноября 2014 г. Тогда же члены ВТО смогли достичь консенсуса о включении Соглашения по упрощению торговых процедур в нормативную базу ВТО.

\section{Tsukanova T. ${ }^{1}$}

\section{Public stockholding for food security in WTO negotiations}

\section{Some issues of WTO regulations of trade in agricultural goods}

Different issues of multilateral regulation of trade in agricultural goods are analyzed: obligations of RF in respect of agricultural subsidies, current status and prospects of Doha negotiations on agriculture, WTO regulations and food security issues in developing countries.

Key words: trade in agricultural goods, agreement on agriculture WTO, obligations, food security, agricultural subsidies, Doha round, trade restrictions.

1 Tsukanova Tatiana - Counselor of the Mission of the Russian Federation to the WTO. 